\title{
Bio-optical properties of the subtropical North Atlantic. I. Vertical variability
}

\author{
Heather A. Bouman ${ }^{1 *}$, Trevor Platt ${ }^{2}$, Gijsbert W. Kraay ${ }^{3}$, \\ Shubha Sathyendranath ${ }^{4}$, Brian D. Irwin ${ }^{2}$
}

\author{
${ }^{1}$ Department of Biology, Dalhousie University, Halifax, Nova Scotia, B3H 4J1, Canada \\ ${ }^{2}$ Bedford Institute of Oceanography, PO Box 1006, Dartmouth, Nova Scotia, B2Y 4A2, Canada \\ ${ }^{3}$ Netherlands Institute of Sea Research, PO Box 59, 1790 AB Den Burg. The Netherlands \\ ${ }^{4}$ Department of Oceanography, Dalhousie University, Halifax, Nova Scotia, B3H 4J1, Canada
}

\begin{abstract}
Studies of the physiological and optical properties of phytoplankton of the subtropical open ocean are rare. Yet, assessing the spatial and temporal variation in the photo-physiological parameters and chlorophyll-specific absorption coefficients of marine phytoplankton is essential if we are to account for the relative importance of pelagic systems in the global carbon economy. As a contribution to this general goal, the photosynthetic and bio-optical properties of phytoplankton were measured at 5 stations across a broad swath of the subtropical North Atlantic Ocean. Similar vertical patterns in pigment composition, chlorophyll-specific absorption coefficients and the photosynthesisirradiance parameters were observed at all 5 stations. A considerable proportion of the vertical variation in the chlorophyll-specific absorption coefficients was caused by vertical changes in the proportion of the non-photosynthetic pigment (NPP) zeaxanthin relative to chlorophyll $a$. On the other hand, pigment packaging appeared to have a minor influence on the optical characteristics of the picoplankton-dominated region: chlorophyll-specific absorption coefficients observed at the red peak frequently exceeded $0.02 \mathrm{~m}^{2}(\mathrm{mg} \mathrm{chl} \mathrm{a})^{-1}$. Multiple, linear-regression analysis was used to examine the value of some commonly-measured environmental variables as potential predictors of the photosynthetic parameters $\alpha^{B}$ and $P_{\mathrm{m}}^{B}$. The results showed that indices of ambient irradiance, nutrient flux or nutrient concentration, separately or in combination, account for a significant fraction of the total variance in the photosynthetic parameters. The stability in the distribution patterns of both the photosynthetic parameters and absorptive characteristics of subtropical phytoplankton assemblages and in the principal factors governing the variability in these properties may facilitate the selection of appropriate input parameters for use in models of primary production for this hydrographic region.
\end{abstract}

KEY WORDS: Absorption spectrum - Photosynthesis - Phytoplankton - Subtropical North Atlantic

\section{INTRODUCTION}

The use of bio-optical models to transform synoptic images of phytoplankton biomass collected by satelliteborne, ocean-colour sensors into large-scale maps of primary production requires the allocation of appropriate parameters to describe the optical characteristics

-E-mail: hbouman@is2.dal.ca and photosynthetic performance of phytoplankton (Platt et al. 1991, Sathyendranath et al. 1995). It is well known that the bio-optical properties of phytoplankton vary over the world ocean. At present, there is no routine method that can be used to derive information on the photosynthetic properties of phytoplankton from remotely sensed data: instead, biological oceanographers must rely on information on the photosynthesis-irradiance (P-I) relationship obtained from conventional experiments conducted on ships. Consequently, over the 
years, a considerable effort has been made by biological oceanographers to obtain information on the intraand inter-seasonal variations in phytoplankton absorption and photosynthetic performance for a variety of oceanic regions. However, the spatial coverage of P-I data remains sparse, especially in open-ocean domains, and, as a result, P-I parameters must be extrapolated over large spatial scales (Platt \& Sathyendranath, 1988). Although steady progress has been made in obtaining greater spatial.and temporal resolution of both P-I and optical data, wide expanses of the world ocean remain undersampled. One region where such data are particularly wanting is the subtropical open ocean (Longhurst et al. 1995, Sathyendranath et al. 1995).

To address the paucity of bio-optical data collected in subtropical waters, several recent studies have focussed on such regions (Babin et al. 1996, Lazzara et al. 1996, Allali et al. 1997). These stratified, open-ocean waters exhibit strong vertical gradients of density, temperature, nutrients and light regime, which in turn promote vertical changes in species composition (Partensky et al. 1996) and in the optical (Babin et al. 1996, Lazzara et al. 1996; Allali et al. 1997) and physiological status (Babin et al. 1996) of phytoplankton. Because the absorption spectrum of phytoplankton is used to approximate the shape of the photosynthetic action spectrum, and to model the attenuation of light beneath the sea surface in spectral models of primary production, it is important that we improve our understanding of the principal factors that cause variations in the optical. properties of marine phytoplankton. It has been found that a significant portion of the observed vertical variation in both the shape and magnitude of the phytoplankton absorption spectrum can be ascribed to the presence of non-photosynthetic pigments (NPPs) (Bricaud \& Stramski 1990, Sosik \& Mitchell 1995, Babin et al. 1996, Lazarra et al. 1996, Allali et al. 1997).

It is also important that we further our knowledge of the magnitude and variation in the P-I parameters in different hydrographic regions over different seasons, to facilitate selection of input parameters for existing models of primary production. It would be advantageous if we could obtain estimates of the P-I parameters using information on more-easily-measured environmental variables, especially those that can be remotely sensed, such as sea-surface temperature. Unfortunately, relationships between the P-I parameters and environmental variables are often obscured by simultaneous changes in several environmental variables (Sosik 1996) and are likely to change across hydrographic regions and seasons (Kyewalyanga et al. 1998).

Keeping in mind the issues presented above, the present study has 2 principal objectives: these are, first, to investigate the variation in the bio-optical and photosynthetic properties of subtropical phytoplank- ton across the North Atlantic Basin; and, second, to examine the correlation of the photosynthetic parameters with the biological and environmental variables that are believed to influence their magnitudes. In a companion paper (Bouman et al. 2000, in this issue), the results are applied to the calculation of primary production using a spectral model.

\section{MATERIALS AND METHODS}

The field observations were made during the Deep Chlorophyll Maximum (DCM) expedition. The main objective of the expedition was to study the dynamics of plankton communities residing in the oligotrophic open ocean under stratified conditions, where the mixed-layer depth is substantially above the euphotic depth, and where a pronounced subsurface-chlorophyll maximum is present. To accomplish this goal, 5 stations were sampled in the middle of the North Atlantic basin on a transect between the continents of South America and Africa (Fig. 1). The stations were chosen such that influence of terrigenous material would be minimal. Sampling was conducted on the RV 'Tydeman' from 26 July to 28 August 1996. Five major stations, approximately equally spaced along the transect, were each occupied over $5 \mathrm{~d}$. On these stations, CTD (Conductivity, Temperature, Density) rosette casts were taken every $3 \mathrm{~h}$ to measure variations in biological and environmental variables of interest over time scales of $<1$ d. During transit between the major stations, single CTD casts were taken daily.

Pigment composition. For each of the time-series stations, pigment samples were collected at 10 depths, between 10 and $180 \mathrm{~m}$ on the first day of sampling. Twenty litres of seawater were filtered through $47 \mathrm{~mm}$ $\mathrm{GF} / \mathrm{F}$ filters. The filters were frozen immediately at

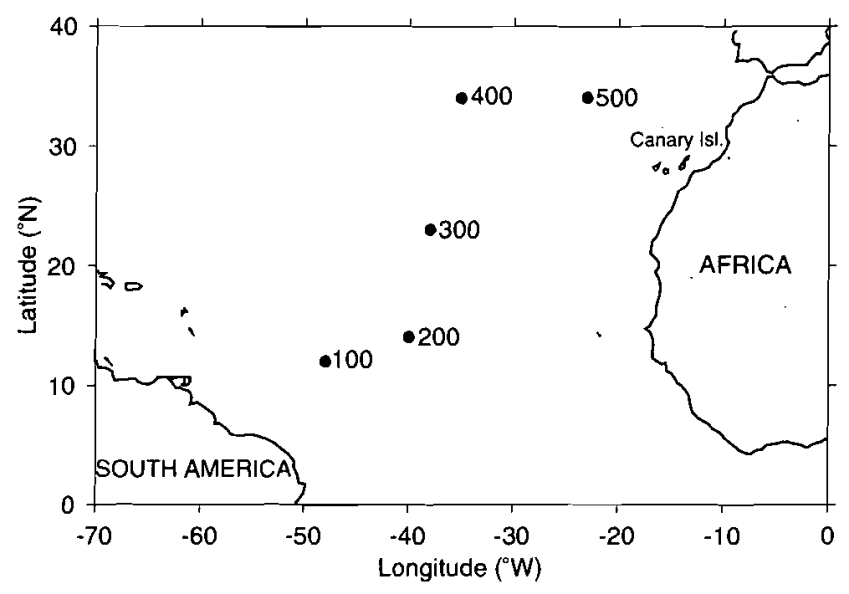

Fig. 1. Location of the 5 major stations covered during the DCM 1996 cruise from 26. July to 28 August 
$-80^{\circ} \mathrm{C}$, and stored until analysed by HPLC (high-performance liquid chromatography). Pigment extraction was carried out according to the protocol described in Veldhuis \& Kraay (1990) and Kraay et al. (1992). This method allowed for the separation of the NPP zeaxanthin from lutein.

The pigments recovered by HPLC analysis were partioned into 2 main groups: photosynthetic and nonphotosynthetic (see Table 1), based on the information presented in Bidigare et al. (1990). The relative concentrations of these 2 pigment groups were used to estimate the proportion of absorbed light that is photosynthetically utilisable. Calculations involved in the determination of absorption by photosynthetic pigments alone will be described in the next section.

Absorptive properties. Small disks $(1.3 \mathrm{~cm}$ diameter) were cut from the frozen $G F / F$ filters collected for HPLC analysis. These subsamples were used to measure the absorption spectrum of particulate matter retained on the filter. Measurements of optical densities of total particles were made using a SPECTRONIC $^{\oplus}$ GENESYS ${ }^{\text {TM }} 2$ PC spectrophotometer with a splitbeam, dual detector optical system. The optical density was recorded in the spectral range from 380 to $750 \mathrm{~nm}$ at a resolution of $1 \mathrm{~nm}$. For each of the measured spectra, the optical density obtained at $750 \mathrm{~nm}$ was subtracted from that at all other wavelengths. The optical density spectrum of total particulate matter, $O_{\mathrm{T}}(\lambda)$, was then calculated as a function of wavelength $\lambda$ by subtracting the optical density spectrum of the reference filter from that of the sample spectrum.

To estimate the spectral absorption by detrital material, the method proposed by Kishino et al. (1985) was modified according to the protocol described in Hoepffner \& Sathyendranath (1992). The extracted filters were then wetted and scanned from 380 to $750 \mathrm{~nm}$ to

Table 1. Main pigments determined using HPLC analysis on field samples collected during the DCM cruise. The pigments are partitioned into photosynthetic and non-photosynthetic categories based on the classification scheme presented in Bidigare et al. (1990)

\begin{tabular}{|ll|}
\hline Photosynthetic pigments & Non-photosynthetic pigments \\
\hline Chlorophyll $a$ & Diadinoxanthin \\
Divinyl chlorophyll $a$ & $\beta$-carotene \\
Chlorophyll $b$ & $\alpha$-carotene \\
Divinyl chlorophyll $b$ & Zeaxanthin \\
Chlorophyll $c 1$-like & \\
Chlorophyll $c 2$ & \\
Chlorophyll $c 3$ & \\
Peridinin & \\
19' butanoyloxy-fucoxanthin & \\
19' hexanoyloxy-fucoxanthin & \\
Fucoxanthin & \\
\hline
\end{tabular}

measure the optical density of the bleached matter, $O_{\mathrm{d}}(\lambda)$. The optical density of the acetone-soluble phytoplankton pigments on the filter, $O_{p}(\lambda)$, was calculated by subtracting $O_{\mathrm{d}}(\lambda)$ from $O_{\mathrm{T}}(\lambda)$.

Moore et al. (1995) reported that, depending on the optical density of the sample, an overestimation of absorption by as much as a factor of 2 could result if a $\beta$ factor derived from diatom cultures was applied to a sample dominated by prochlorophytes. Divinyl chlorophyll $a$, which is a marker for prochlorophytes, can be distinguished from chlorophyll $a$, the principal lightharvesting pigment for all other phytoplankton groups, by HPLC analysis. At each of the 5 stations, the percentage of total chlorophyll that was divinyl chlorophyll $a$ was high, in some cases exceeding $50 \%$. If we assume that, for both prochlorophytes and the remaining microalgae, absorption is proportional to the concentration of these 2 forms of chlorophyll $a$, we can correct for the filter effect by using the formula presented in Kyewalyanga et al. (1998):

$$
\begin{aligned}
O_{\mathrm{s}}(\lambda)= & F_{\mathrm{dv}}\left\{A_{1} O_{\mathrm{p}}(\lambda)+B_{1}\left[O_{\mathrm{p}}(\lambda)\right]^{2}\right\} \\
& +\left(1-F_{\mathrm{dv}}\right)\left\{A_{2} O_{\mathrm{p}}(\lambda)+B_{2}\left[O_{\mathrm{p}}(\lambda)\right]^{2}\right\}
\end{aligned}
$$

where $O_{s}$ is the optical density of particulate matter in suspension. In this equation, the measured optical densities $\left[O_{p}(\lambda)\right]$ are assigned to 2 different $\beta$-factors based on the ratio of divinyl chlorophyll a to total chlorophyll a concentration, $F_{\mathrm{dv}}$. The coefficients $A_{1}$ and $B_{1}(0.29$ and 0.05 , respectively) correspond to the algorithm appropriate for prochlorophytes (Moore et al. 1995), whereas $A_{2}$ and $B_{2}$ (0.31 and 0.57 , respectively) correspond to the algorithm appropriate for the rest of the phytoplankton community (Hoepffner \& Sathyendranath 1992). The vector of quantities $O_{s}(\lambda)$, determined from Eq. (1), was then converted to a vector of absorption coefficients, $a_{\mathrm{ph}}(\lambda)$ in values per metre, by the transformation (Mitchell \& Kiefer 1988):

$$
a_{\mathrm{ph}}(\lambda)=2.3 \cdot O_{\mathrm{s}}(\lambda) \cdot(S / V)
$$

applied at each wavelength $\lambda$, where $S$ is the clearance area of the filter, $V$ is the volume of seawater filtered, and the constant 2.3 converts from base 10 logarithms to natural logarithms. Finally, each absorption spectrum was normalised to HPLC-determined total chlorophyll a concentration (the sum of divinyl chlorophyll $a$ and chlorophyll $a$ ) to obtain the chlorophyll-specific absorption spectrum, $a_{\mathrm{ph}}^{B}(\lambda)$.

When using the absorption spectrum of phytoplankton to approximate the shape of the photosynthetic action spectrum it is desirable to include only the absorption by photosynthetically-active pigments $\left(a_{\mathrm{ps}}^{B}\right.$ in the notation of Sosik 1996). Since subtropical phytoplankton may contain large proportions of NPPs we used the following equation presented in Babin et al. (1996) to subtract the absorption by NPPs: 


$$
a_{\mathrm{ps}}^{B}(\lambda)=a_{\mathrm{ph}}^{B}(\lambda)\left[1-C_{\mathrm{np}}(\lambda)\right]
$$

where $a_{\mathrm{ps}}^{B}$ is the approximated, in vivo phytoplankton absorption spectrum of the photosynthetically active pigments and $a_{\mathrm{ph}}^{B}$ is the measured in vivo absorption spectrum by phytoplankton, which includes absorption by both photosynthetic and non-photosynthetic pigments. The quantity $c_{\mathrm{np}}(\lambda)$ is computed using information on the concentrations of the various pigments found in the sample and their associated weightspecific absorption coefficients (Bidigare et al. 1990), as follows:

$$
c_{\mathrm{np}}(\lambda)=\frac{\sum_{m=1}^{n p} c_{\mathrm{m}} a_{\mathrm{m}}^{*}(\lambda)}{\sum_{m=1}^{n} c_{\mathrm{m}} a_{\mathrm{m}}^{*}(\lambda)},
$$

where $a_{\mathrm{m}}^{*}(\lambda)$ is the weight-specific absorption coefficient of the $m$ th pigment in solvent at wavelength $\lambda$, $c_{\mathrm{m}}$ is the concentration of the $m$ th pigment, $n p$ is the total number of NPPs in the sample and $n$ is the total number of all pigments in the sample (Babin et al. 1996). The corrected spectrum $a_{\mathrm{ps}}(\lambda)$ was used to approximate both the absorption coefficient for photosynthetic pigments and to correct for the emission spectrum of the lamp used in our P-I experiments.

Photosynthesis-irradiance experiments. At each of the time-series stations, P-I experiments were performed on samples collected at several depths to obtain information on the vertical changes in the photosynthetic parameters within the euphotic zone. Experimental data were then fitted to the equation of Platt et al. (1980) to obtain the 2 parameters that characterise the shape of the photosynthesis-irradiance curve: the initial slope $\left(\alpha^{B}\right)$ and the photosynthetic rate at saturating irradiance $\left(P_{\mathrm{m}}^{B}\right)$.

The emission spectrum of the tungsten-halogen lamp used in the P-I experiments is not spectrally neutral, but is strongly wavelength-dependent, with an emission minimum in the blue and an emission maximum in the red. Because $\alpha(\lambda)$ is also wavelength dependent, the values of $\alpha^{B}$ must be corrected for the shape of the action spectrum and the shape of the emission spectrum of the lamp (Dubinsky et al. 1986, Arrigo \& Sullivan 1992, Kyewalyanga et al. 1997). To correct for these biases, the initial slope was multiplied by a correction factor, which we designate as $X$. In view of the close correspondence between absorption and action spectra (Haxo \& Blinks 1950), $X$ is based on the absorption spectrum of phytoplankton, and assumes that the maximum quantum yield of photosynthesis $\left[\phi_{m}(\lambda)\right]$ is spectrally flat.

The correction factor $X$ is defined as the ratio of the unweighted, spectral-mean photosynthetic absorption of phytoplankton $\left(\bar{a}_{\mathrm{ps}}\right)$ to the mean photosynthetic absorption of phytoplankton weighted by the shape of the emission spectrum of the tungsten-halogen lamp $\left(\bar{a}_{T}\right)$, and therefore is given by:

$$
X=\bar{a}_{\mathrm{ps}} / \overline{\boldsymbol{a}}_{\mathrm{T}},
$$

The value of $\left(\bar{a}_{\mathrm{ps}}\right)$ was computed as follows:

$$
\bar{a}_{\mathrm{ps}}=\frac{\int_{400}^{700} a_{\mathrm{ps}}(\lambda) \mathrm{d} \lambda}{\int_{400}^{700} \mathrm{~d} \lambda}
$$

where $a_{\mathrm{ps}}(\lambda)$ is the absorption coefficient of photosynthetically-active pigments at wavelength $\lambda$. The mean photosynthetic absorption of phytoplankton, weighted by the shape of the emission spectrum of the tungstenhalogen lamp, was obtained by:

$$
\bar{a}_{\mathrm{T}}=\frac{\int_{400}^{700} a_{\mathrm{ps}}(\lambda) I_{\mathrm{T}}(\lambda) \mathrm{d} \lambda}{\int_{400}^{700} I_{\mathrm{T}}(\lambda) \mathrm{d} \lambda},
$$

where $I_{\mathrm{T}}$ is the spectral irradiance incident during the experiment. The photosynthetic absorption $a_{\mathrm{ps}}(\lambda)$, rather than total phytoplankton absorption $a_{\mathrm{ph}}(\lambda)$, was used in the computation of $X$. In this respect, our calculation of correction factors differs from similar calculations by Dubinsky et al. (1986), Schofield et al. (1991), Babin et al. (1995) and Kyewalyanga et al. (1997). For comparison with the earlier work, we did calculate correction factors using total absorption: they showed a strong depth dependence (Fig. 2), which appeared to be influ-

\section{$X$ (Lamp Correction Factor)}

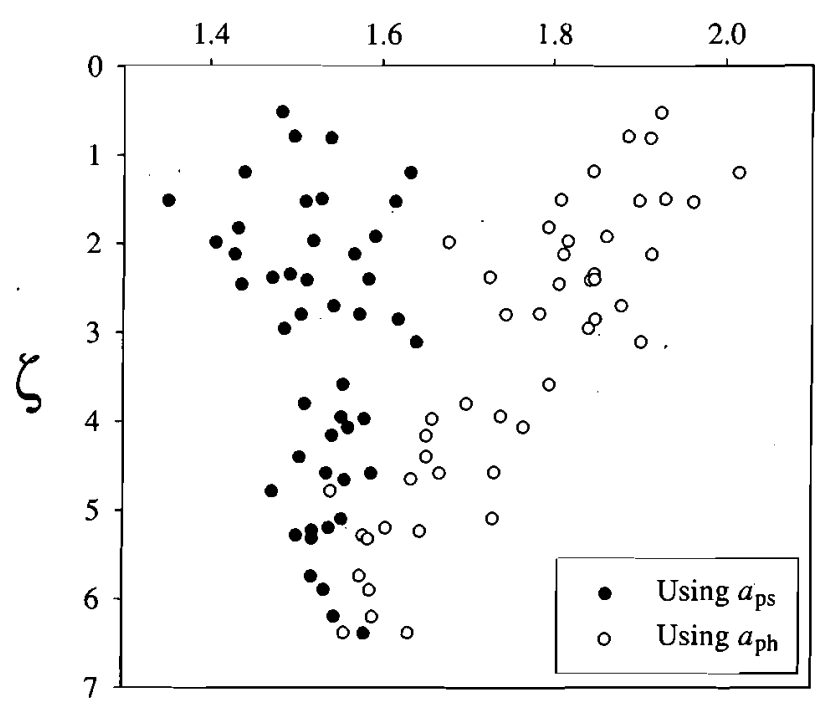

Fig. 2. Vertical profiles of the ratio $X$ used to correct values of $\alpha^{B}$ for the spectral quality of the incubation lamp. Open circles represent correction factors calculated using the total phytoplankton absorption spectra $a_{\mathrm{ph}}^{B}(\lambda)$. Filled circles represent correction factors calculated from photosynthetically-utilisable absorption spectra $a_{p s}^{B}(\lambda)$, which were obtained using the method described in Babin et al. (1996) 

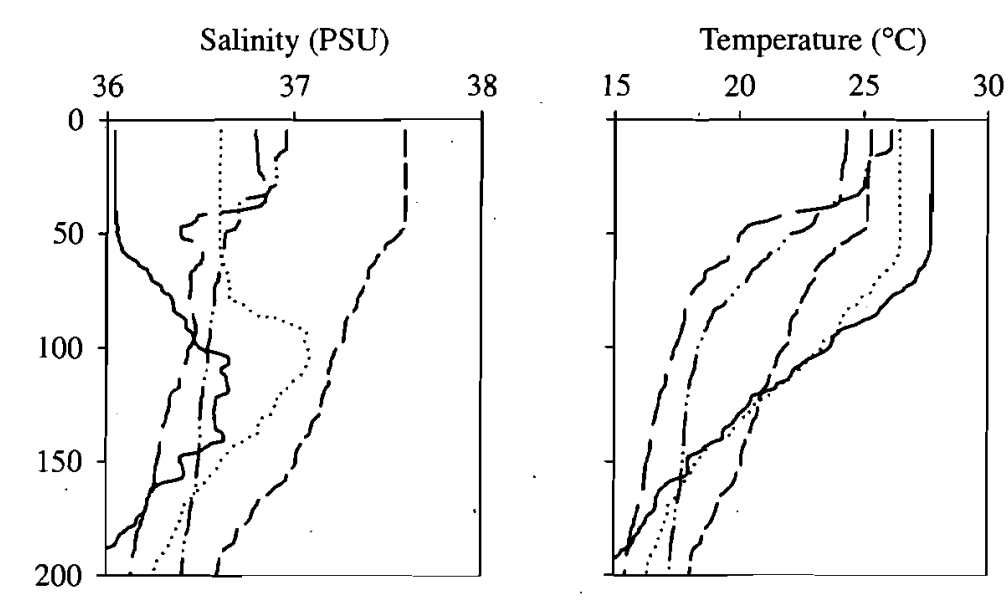

政

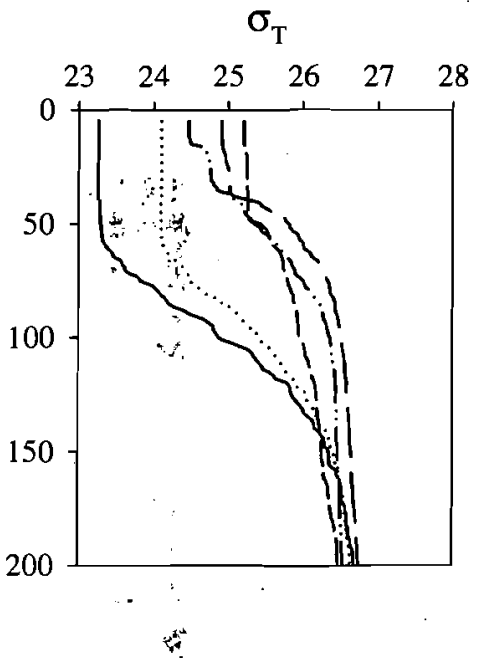

Fig. 3. Vertical profiles of salinity, temperature and density $\left(\sigma_{\mathrm{T}}\right)$ taken from the first CTD cast for Stns 100 to 500

enced by the absorption by NPPs. The photosynthetic action spectrum should be unaffected by the presence or absence of NPPs and so it would be preferable to use the $a_{p s}(\lambda)$ spectrum to derive the correction factor.

The $X$ values computed using $a_{\mathrm{ps}}(\lambda)$ appear to be less variable with respect to depth than correction factors that were derived using the shape of $a_{\mathrm{ph}}(\lambda)$ (Fig. 2). This low degree of variation in the correction factor calculated using estimates of $a_{p s}(\lambda)$ is convenient in instances where there is no information on the absorption and pigment properties of the phytoplankton accompanying measurements of $\alpha^{B}$. For values of $\alpha^{B}$ where photosynthetic absorption was not obtained, a mean correction factor of 1.52 was applied.

Chlorophyll a concentrations were determined on the same water sample used for the P-I experiments, from fluorescence of the pigment extracts before and after acidification in a Turner Designs fluorometer (Holm-Hansen et al. 1965). Although it has been re- ported that the presence of high concentrations of chlorophyll $b$ can introduce a bias to measurements of chlorophyll a concentrations determined using the fluorometric method (Gibbs 1979), linear-regression analysis of all HPLC $\left(C_{\mathrm{H}}\right)$ and fluorometric $\left(C_{\mathrm{F}}\right)$ chlorophyll a data obtained in this study did not show any significant bias $\left(C_{\mathrm{F}}=\right.$ $0.91 C_{\mathrm{H}}+0.02, \mathrm{r}^{2}=0.84$ ). It should be noted that all P-I parameters were normalised to fluorometrically-determined chlorophyll $a$. Micromolar determination of $\mathrm{NO}_{2}$ and $\mathrm{NO}_{3}$ concentrations were made on the same water sample using a Technicon Autoanalyzer $^{(8)}$ system. Vertical profiles of temperature, salinity and chlorophyll a fluorescence were measured using a CTD (Sea-Bird Electronics Inc.) and an in situ fluorometer (Chelsea Inc.).

Measurements of downwelling, vector spectral irradiance obtained using the Advanced Spectral Irradiance Meter (ASIR) (Wernand \& Spitzer 1987) at 22 spectral bands were used to tune the light-attenuation algorithm presented in Sathyendranath \& Platt (1989). Using the algorithm, spectral irradiance was integrated over the visible wavebands to obtain a value of photosynthetically-active irradiance at depth $z[\operatorname{PAR}(z)]$. The rate of decrease in the logorithm of $\operatorname{PAR}[K(z)]$ was also computed and multiplied by depth $z$ to arrive at an estimate of optical depth $(\zeta)$.

\section{RESULTS}

\section{Hydrological conditions of sampling area}

For all of the stations, density profiles determined by CTD measurements reveal the presence of a welldefined mixed layer (Fig. 3). In all cases, the mixedlayer depths were found to lie well above the euphotic depth. At the 2 western-most stations (100 and 200), a stronger density gradient was present than that observed at the 3 eastern-most stations $(300,400$ and 500). The differences in density profiles observed at these sites are caused primarily by differences in the vertical structure of salinity.

The presence of a subsurface chlorophyll maximum is a common characteristic of the open-ocean environments in the (sub)tropics (Cullen 1982, Herbland 1983) and was observed in the vertical profiles of fluorometrically determined chlorophyll a concentration (Fig. 4). Concentrations of chlorophyll $a$ were extremely low 


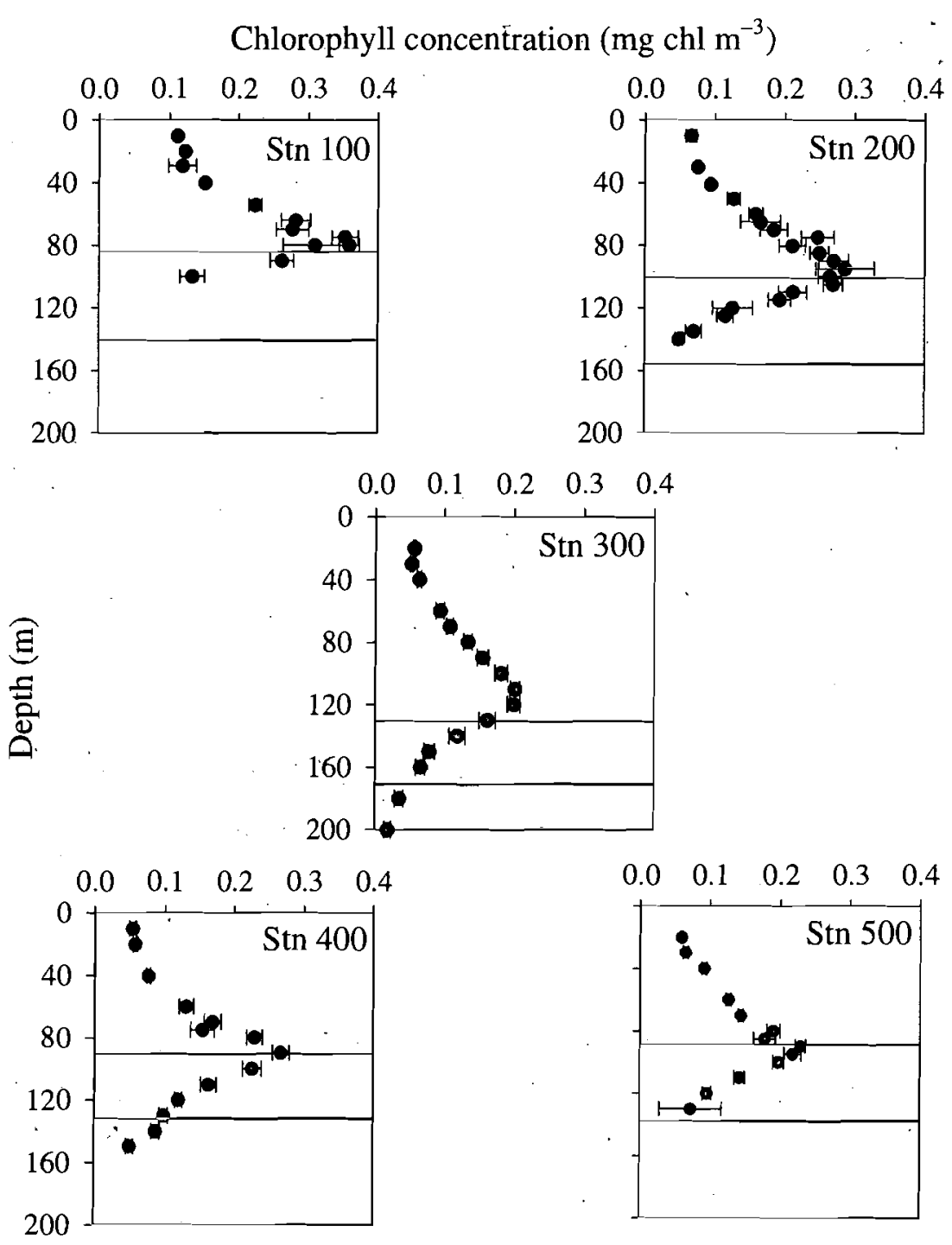

Fig. 4. Mean vertical profiles of fluorometrically determined chlorophyll a concentration for Stns 100 to 500. Bars represent one standard error from the mean value. Marked on each profile is the depth of the euphotic zone (upper horizontal line) determined using spectral irradiance measurements and the light-attenuation algorithm of Sathyendranath \& Platt (1989), and the mean depth of the nitricline (lower horizontal line), which we define as the first depth at which the nitrate concentration exceeds $0.5 \mu \mathrm{M}$

throughout the water column at all of the stations, ranging from $<0.1 \mathrm{mg} \mathrm{chl} a \mathrm{~m}^{-3}$ at the surface to between 0.23 and $0.36 \mathrm{mg} \mathrm{chl} \mathrm{a} \mathrm{m}^{-3}$ at the chlorophyll maximum. A time series constructed from depthresolved, fluorometrically determined chlorophyll a concentrations and in situ fluorescence measurements taken from the CTD meter revealed a vertical oscillation of 20 to $30 \mathrm{~m}$ in the chlorophyll and fluorescence maximum. The periodic fluctuations in the fluorescence and chlorophyll peaks were likely caused by the presence of internal waves. On average, the depth of the chlorophyll maximum ranged from $75 \mathrm{~m}$ at Stn 100 to $110 \mathrm{~m}$ at Stn 300 .

The vertical structure of nitrate concentration was characteristic of oligotrophic conditions, with concentrations within the mixed layer usually falling below the limit of detection. Nitricline depths ranged from about $80 \mathrm{~m}$ at Stn 100 to $150 \mathrm{~m}$ at Stn 300 (Fig. 4) and, like the depth of the chlorophyll maximum, oscillated vertically under the influence of internal waves.

\section{Pigment composition}

Vertical gradients in both the intensity and spectral quality of the underwater irradiance field are known to cause changes in pigment composition and concentration, as well as shifts in species composition (Wood 1985, Veldhuis \& Kraay 1990, Claustre \& Marty 1995, Partensky et al. 1996). The stratification of different algal populations and their associated pigments within the water column will influence the vertical structure of the optical and photo-physiological characteristics of microalgae. Therefore, vertical variations in pigment composition and concentration were examined using HPLC data to develop a better understanding of the variability in the bio-optical properties of phytoplankton that were measured in this study.

The high abundance of Prochlorococcus cells was evident in the results obtained by HPLC analysis. Divinyl chlorophyll a (DVChl-a), a pigment marker of Prochlorococcus, contributed substantially to the total chlorophyll a (TChl-a, the sum of DVChl-a and Chl-a) concentration: the ratio of DVChl- $a$ to TChla concentration exceeded $50 \%$ in several of the pigment samples. Another diagnostic pigment of prochlorophytes, divinyl chlorophyll $b$ (DVChl- $b$ ), was also abundant: at the DCM over $80 \%$ of the total chlorophyll $b$ (TChl- $b$ ) concentration was in the form of DVChl- $b$.

Changes in pigment composition with depth were noted in profiles of accessory-pigment concentrations normalised to TChl-a pigment concentration. Profiles of the TChl- $b$ to TChl- $a$ ratio (TChl-b/TChl-a) (Fig. 5a) 
TChl- $b$ / TChl- $a$

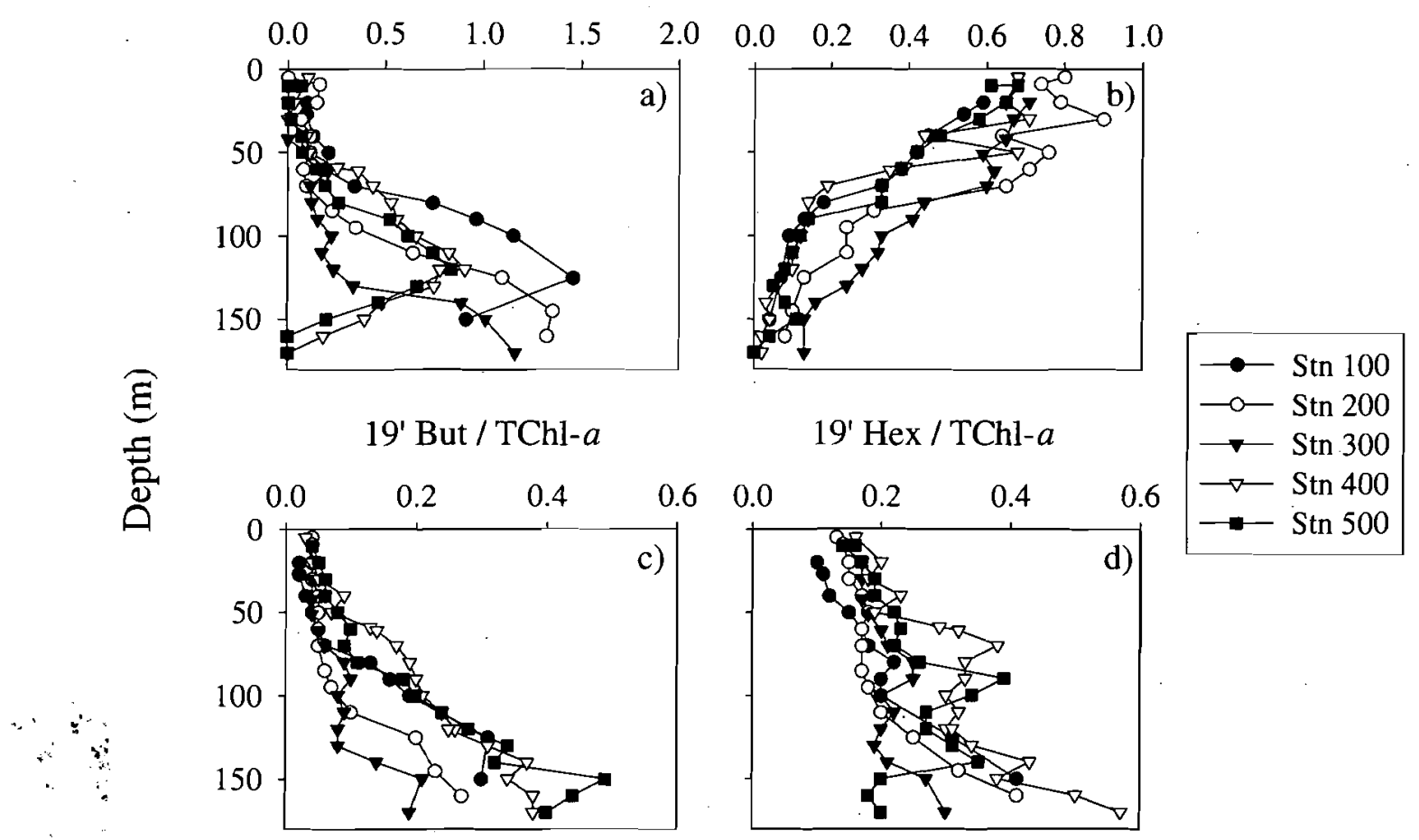

Fig. 5. Vertical profiles of total chlorophyll $a$ (TChl-a) normalised concentrations of (a) total chlorophyll $b$ (TChl-b), (b) zeaxanthin (Zeax), (c) 19'-butanoyloxy-fucoxanthin (19' But) and (d) 19'-hexanoyloxy-fucoxanthin (19' Hex) for Stns 100 to 500

reveal a trend typical of stratified oligotrophic conditions, with deeper samples having very high TChl-b/ TChl-a ratios, in some cases exceeding a value of 1. This is in agreement with similar studies of picoplankton-dominated oligotrophic waters (Goericke \& Repeta 1993, Lazzara et al. 1996, Partensky et al. 1996). Another group of pigments whose relative importance increased with depth was the carotenoids 19'-butanoyloxy-fucoxanthin and 19'-hexanoyloxy-fucoxanthin (Fig. 5c,d). These pigments, present in eukaryotic cells, have an absorption spectrum very similar to that of the measured spectral distribution of irradiance at the depth at which they become significant.

In contrast, chlorophyll-normalised concentrations of the NPP zeaxanthin (Fig. 5b) decreased slowly from the surface to above the DCM, and rapidly within and below the pigment maximum. Zeaxanthin was the most abundant NPP present at all 5 stations, contributing over $80 \%$ of the total NPP concentration. Phaeopigments, which were present at barely detectable concentrations, made a negligible contribution to the total amount of NPPs.

By calculating the weight-to-weight ratio of NPPs to total pigments, referred to as the NPP index (Babin et al. 1996), one can assess the relative importance of NPPs with respect to total pigment concentration (Fig. 6). All stations exhibited similar NPP index profiles, both in

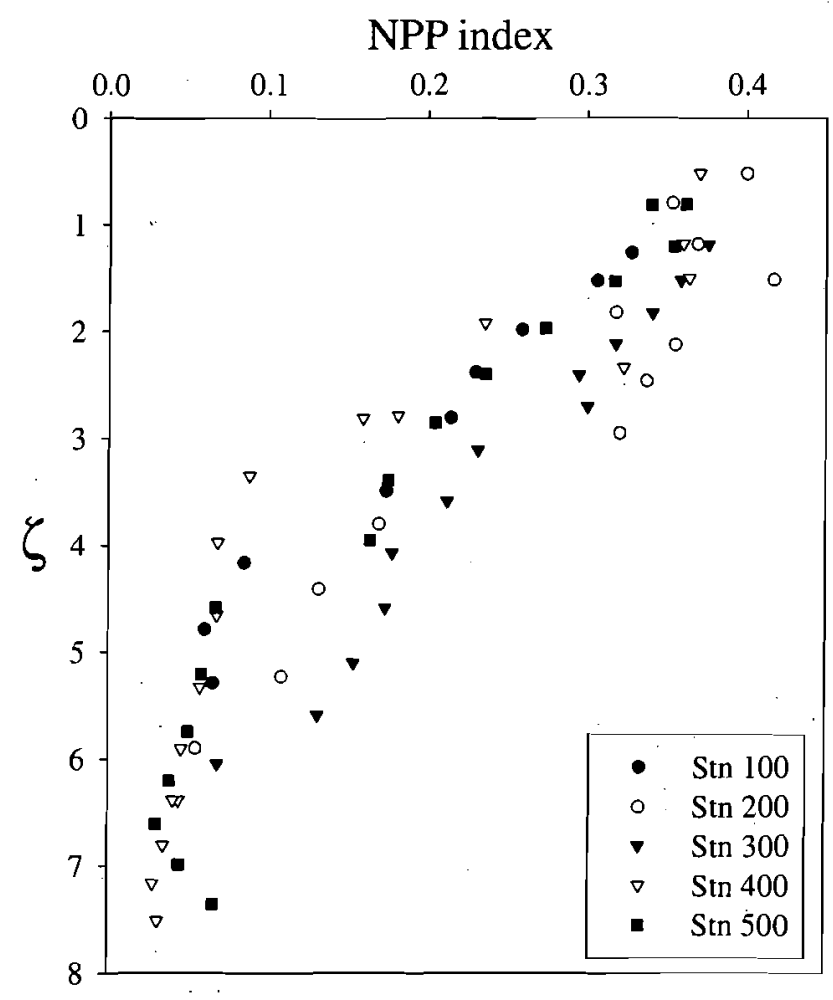

Fig. 6. Weight-to-weight ratio of non-photosynthetic pigment to total pigment concentration (NPP index), as a function of optical depth $(\zeta)$ for the 5 main stations 
shape and magnitude. The NPP index approached values of 0.4 at the surface and decreased gradually with increasing optical depth $\zeta$ (dimensionless), which is defined as the product of the attenuation coefficient of downwelling irradiance $K_{d}\left(\mathrm{~m}^{-1}\right)$ and depth $z(\mathrm{~m})$.

\section{Effect of accessory pigments on $a_{\mathrm{ph}}^{B}(\lambda)$}

To examine the within-station differences in the spectral shape of $a_{\mathrm{ph}}^{B}(\lambda)$, absorption coefficients at each wavelength were normalised with respect to the absorption coefficient of phytoplankton at $440 \mathrm{~nm}$ $\left[a_{\mathrm{ph}}^{B}(440)\right]$ (Fig. 7). The regions of the absorption spectra where the spectral shapes diverge are located

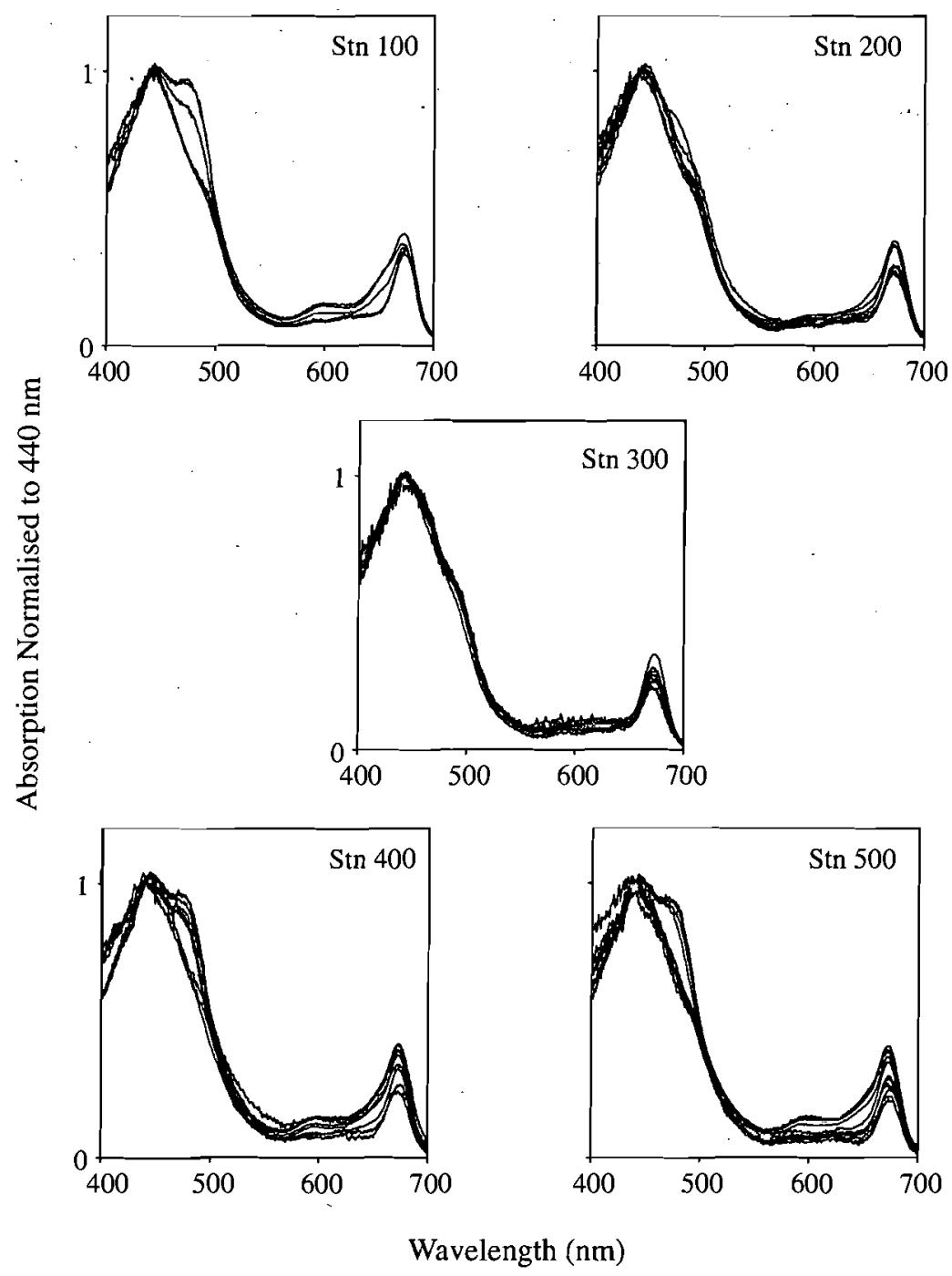

Fig. 7. Phytoplankton absorption spectra normalised to $440 \mathrm{~nm}$ for all samples collected at Stns 100 to 500 around 470 to $480 \mathrm{~nm}$ and $650 \mathrm{~nm}$. Pronounced shoulders of absorption at the blue and red regions of the spectrum found in samples collected deeper in the water column correspond to the wavelengths at which chlorophyll $b$ absorbs strongly. As we have seen in the pigment data, total chlorophyll $b$ concentrations increase markedly with depth relative to the other pigments. Therefore, these differences in the shapes of the absorption spectra can be ascribed to the high concentrations of chlorophyll $b$ at depth (Bricaud \& Stramski 1990, Hoepffner \& Sathyendranath 1992, Lazzara et al. 1996, Allali et al. 1997).

Zeaxanthin was another pigment that exhibited a substantial vertical change in its chlorophyll a-normalised concentration. This NPP absorbs strongly in the blue region of the absorption spectrum. Since the $440 \mathrm{~nm}$ waveband is commonly used in various optical algorithms, we examined the relative influence of NPPs on the magnitude of $a_{\mathrm{ph}}(440)$, by plotting the percentage of absorption by NPPs at $440 \mathrm{~nm}$ against. the logarithm of irradiance at local noon. The results, summarised in Fig. 8, showed a clear correlation between the percent absorption of NPPs at $440 \mathrm{~nm}$ and the logarithm of irradiance. Note that Fig. 8 is constructed using what we know of the absorption properties of pigments in solvents, and does not account for any potential variability in the in vivo absorption properties of pigments. These data are consistent with those obtained in other studies conducted in oligotrophic marine waters (Hoepffner \& Sathyendranth 1992, Sosik \& Mitchell 1995, Babin et al. 1996, Allali et al. 1997) that attribute a significant portion of the vertical change in the chlorophyll-specific absorption coefficient to the relative concentration of NPPs.

The ratio of maximum absorption by phytoplankton in the blue to that in the red region was also strongly influenced by the varying proportions of NPPs. When the ratios between the blue and the red peak heights $\left[a_{\mathrm{ph}}(440) / a_{\mathrm{ph}}(676)\right]$ were plotted against the NPP index, a clear trend was present (Fig. 9): an increase in the NPP index resulted in a corresponding increase in $a_{\mathrm{ph}}(440) / a_{\mathrm{ph}}(676)$. This result is plausible: since absorption by the NPP zeaxanthin is confined to the blue part of the spectrum, any increase in the concentration of zeaxanthin would result in an increase in absorption coefficients at the blue region relative to the red. 


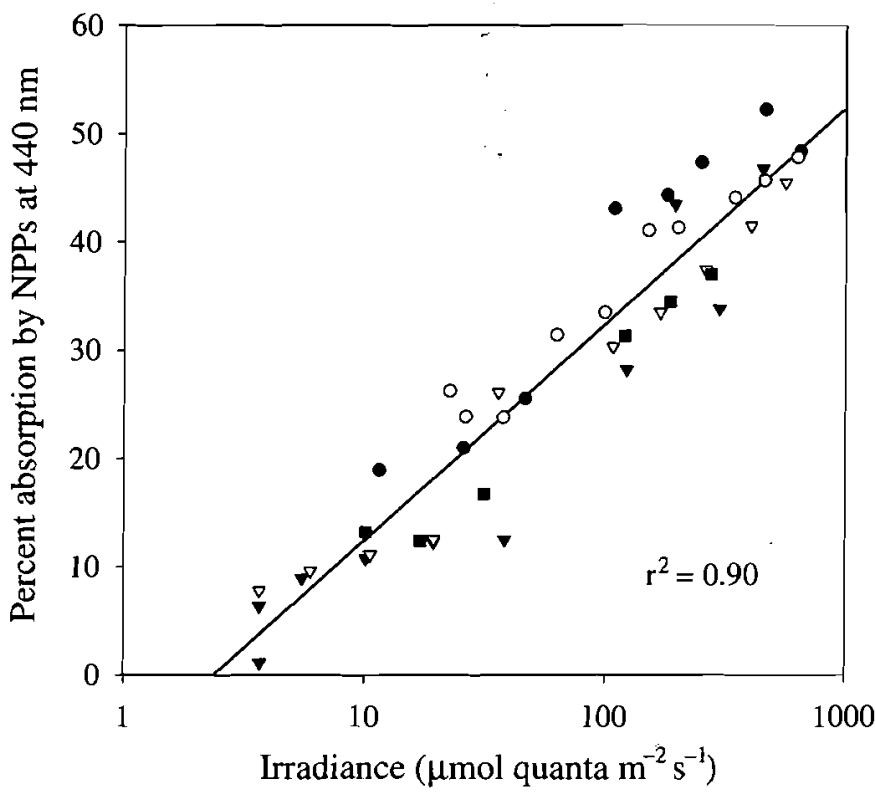

Fig. 8. Estimates of percent absorption by non-photosynthetic pigments (NPPs) at $440 \mathrm{~nm}$ at depth $z$ plotted against mid-day values"of photosynthetically active irradiance at depth $z$. Absorption by NPPs was obtained using the method of Babin et al. (1996). Irradiance values were obtained using the lightattenuation algorithm of Sathyendranath \& Platt (1989). Measurements of in situ spectral irradiance at different wavebands were used to tune the underwater-irradiance model (see Bouman et al. 2000)

\section{Effect of pigment packaging}

Although the magnitude of $a_{\mathrm{ph}}^{B}(\lambda)$ is strongly influenced by the relative concentrations of accessory pigments, pigment packaging can also be an important contributor to variation in the chlorophyll-specific absorption coefficient of marine phytoplankton. Pigment packaging is a function of 2 properties of the cell: its size and its intracellular pigment concentration (Duysens 1956, Platt \& Jassby 1976, Morel \& Bricaud 1981). An increase in either the cell size or the intracellular pigment concentration will result in a corresponding decrease in the absorption efficiency of phytoplankton pigments (Duysens 1956, Platt \& Jassby 1976, Morel \& Bricaud 1981, Sathyendranath et al. 1987). This decrease in the in vivo specific absorption of aggregated pigments, compared with that of the same quantity of pigment evenly dispersed in solution, is referred to as the package or flattening effect (Kirk 1976). The package effect is strongest in regions of the spectrum where absorption is highest and vice versa (Morel \& Bricaud 1981).

One method used to assess the degree to which pigment packaging affects phytoplankton absorption is to compare the in vivo specific absorption coefficient for chlorophyll $a$ at the red peak $(676 \mathrm{~nm})$ with the specific absorption coefficient of pure chlorophyll a at $676 \mathrm{~nm}$ in acetone (Bricaud et al. 1995, Allali et al. 1997). The comparison requires that absorption by pigments other than chlorophyll a be excluded. To achieve this, the in vivo phytoplankton absorption spectrum was first partitioned into contributions from the principal pigments or pigment groups present. We followed the method outlined in Hoepffner \& Sathyendranath (1993), which has the advantage of taking into account the Gaussian shape and position of the absorption bands of the chlorophylls. In applying this technique, it was particularly important to separate contributions by chlorophylls $a$ and $b$ (whose absorption bands overlap at $676 \mathrm{~nm}$ ), which were both prominent in the pigment samples. Estimates of in vivo specific absorption coefficient of chlorophyll $a$ obtained using the spectral decomposition method were consistently greater than the absorption coefficient of unpacked pure chlorophyll a at $676 \mathrm{~nm}$ in solvent $\left(0.021 \mathrm{~m}^{2} \mathrm{mg}^{-1} \mathrm{chl}\right.$ a) (Morel \& Bricaud 1981) (Fig. 10). The implications of these results will be discussed later in the paper.

\section{Variation in the photosynthetic parameters}

The magnitudes of the photosynthetic parameters exhibited clear depth-dependence at all 5 stations. Vertical profiles of $\alpha^{B}$ were low at the surface, slightly

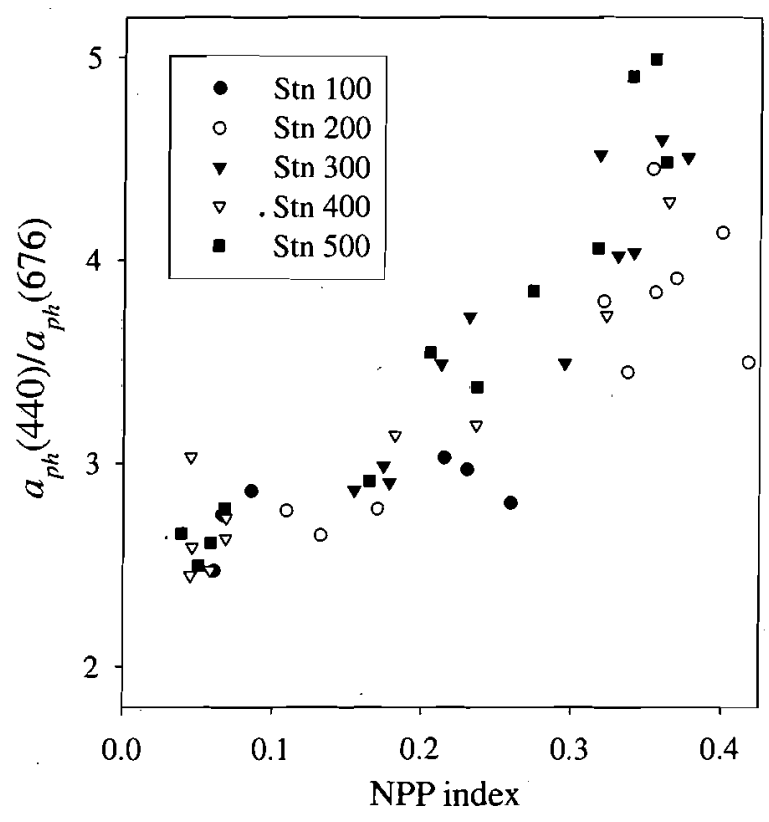

Fig. 9. Relationship between the ratio of the absorption coefficients of phytoplankton at 440 and $676 \mathrm{~nm}, a_{\mathrm{ph}}(440) / a_{\mathrm{ph}}(676)$, and the weight-to-weight ratio of non-photosynthetic pigment to total pigment concentration (NPP index) 


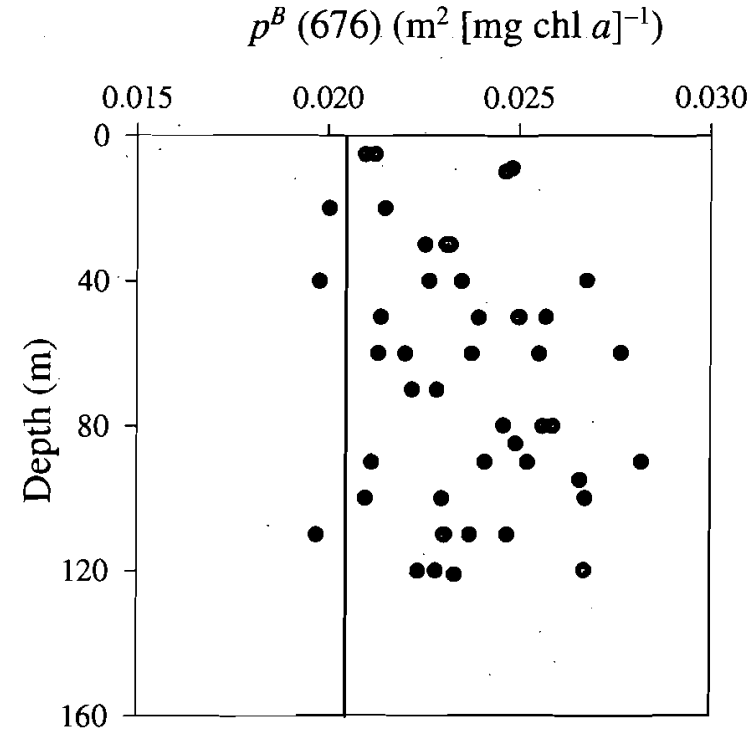

Fig. 10. Vertical profiles of in vivo specific absorption coefficient for chlorophyll $a$ at $676 \mathrm{~nm} p^{B}(676)$ 2...

*

increasing towards the DCM (Fig. 11), and then increasing more rapidly within and below the DCM. On average, a 5-fold change in $\alpha^{B}$ was observed, from the surface to below the DCM. The photosynthetic capacity $\left(P_{\mathrm{m}}^{B}\right)$ and the photoadaptation parameter $\left(I_{k}\right)$ decreased in magnitude with increasing depth (Fig. 11). The variation in $P_{\mathrm{m}}^{B}$ with depth was about 5 -fold, with values ranging from close to $6 \mathrm{mg} \mathrm{C} \mathrm{mg}^{-1} \mathrm{chl} \mathrm{h}^{-1}$ at the surface to values slightly $<1 \mathrm{mg} \mathrm{C} \mathrm{mg}^{-1} \mathrm{chl} \mathrm{h}^{-1}$ below the DCM. The quantity $I_{k}$ exhibited a roughly 10 -fold variation with depth, with values ranging from about $400 \mu \mathrm{mol}$ quanta $\mathrm{m}^{-2} \mathrm{~s}^{-1}$ at the surface to $40 \mu \mathrm{mol}$ quanta $\mathrm{m}^{-2} \mathrm{~s}^{-1}$ at $100 \mathrm{~m}$.
The influence of environmental variables on the P-I parameters was examined using multiple, linear-regression analysis. This statistical model assumes a linear relationship between the dependent and independent variables. Although some studies have shown non-linear correlations between the photosynthetic parameters and different environmental variables, multilinear models can be a useful tool to distinguish which variable or group of variables may be suitable predictors of photosynthetic performance in a particular hydrographic region. Using the statistical package Systat ${ }^{\circledR}$, a stepwise, backward, multiple, linear regression was executed using 5 predictor variables: temperature, optical depth, the ratio of the maximum absorption in the blue and red region of the spectrum (an index of photoadaptation), nitrate concentration (an index of nutrient concentration) and distance from the nitricline (a potential index of nutrient flux). Because the photosynthetic parameter $P_{\mathrm{m}}^{B}$ exhibited diel patterns in its magnitude, only $P_{\mathrm{m}}^{B}$ values obtained from samples collected near local noon were used in the regression analysis. The results of the analysis are shown in Table 2. The best set of predictors for $\alpha^{B}$ was nitrate concentration and optical depth, whereas distance from the nitricline and optical depth were the best set of predictors for the parameter $P_{\mathrm{m}}^{B}$. The best single predictors of $\alpha^{B}$ and $P_{\mathrm{m}}^{B}$ were nitrate concentration and optical depth, respectively.

\section{DISCUSSION}

The vertical structures of pigment composition, photosynthetic response and optical properties of marine phytoplankton in the oligotrophic ocean are governed
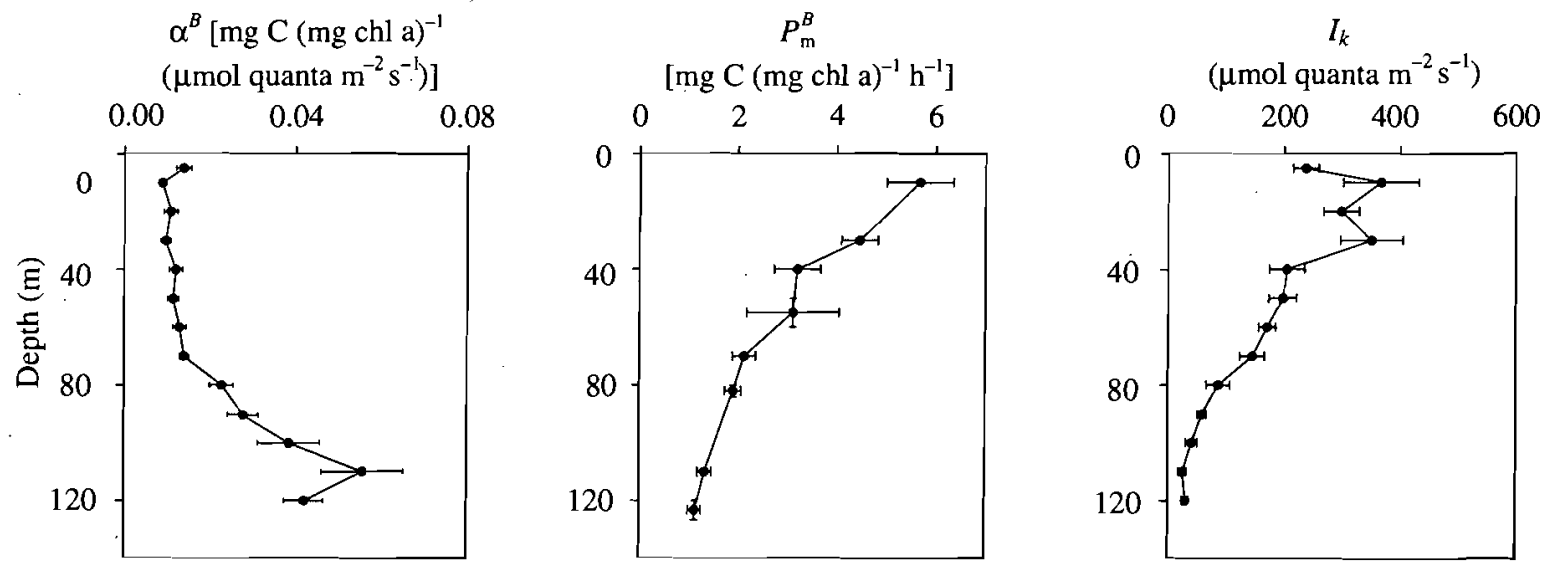

Fig. 11. Mean vertical profiles of photosynthetic efficiency $\alpha^{B}$, photosynthetic capacity $P_{\mathrm{m}}^{B}$, and the photoadaptation parameter $I_{\mathrm{k}}$ calculated from data collected at Stns 100 to 500 . Error bars represent \pm 1 standard error 
by several different physical and chemical factors that vary with depth. Co-variance between these forcing factors prohibits one from ascribing the variation observed in the physiological properties of the phytoplankton to any single environmental factor (Sosik 1996). However, simultaneous measurement of several key physico-chemical and biological quantities permits examination of the relationships and patterns that occur between biological properties and the environmental conditions that regulate them. By comparing relationships established on the basis of observations in the field with single-factor relationships obtained in the laboratory using cultures, we can try to elucidate the primary environmental variables controlling primary production in the subtropical ocean (Sosik 1996).

Photoacclimation of the phytoplankton cells is evident in the vertical profiles of chlorophyll a specific pigment concentrations. When compared with chlorophyll $a$, the concentration of chlorophyll $b$ increased markedly with depth. A large component of this vertical increase in total chlorophyll $b$ concentration was caused by the photoacclimation of Prochlorococcus. Accumulation of high amounts of divinyl chlorophyll $b$ in low-light acclimated Prochlorococcus cells has been documented in both field and laboratory experiments (Partensky et al. 1993, Claustre \& Marty 1995, Moore et al. 1995, 1998, Lazzara et al. 1996).

Increasing concentrations of chlorophylls $a$ and $b$ with depth, and probably absorption by yellow substances (Bouman et al. 2000), resulted in a vertical shift in the spectral irradiance field from the blue-green to the green. This was accompanied by a decrease in the chlorophyll a normalised concentration of total chlorophyll $b$ pigment and an increase in chlorophyll $a$ nor'malised concentrations of the carotenoids 19'-hexa-

Table 2. Results of backward, stepwise, multiple, linear-regression analysis for the photosynthetic parameters $\alpha^{B}$ and $P_{\mathrm{m}}^{B}$. Data were pooled over all depths and stations with the exception that only $P_{\mathrm{m}}^{B}$ values obtained from samples collected near local noon were used to eliminate the influence of strong diel changes in this quantity. Predictor variables used in the analysis were temperature $\left(T,{ }^{\circ} \mathrm{C}\right)$, optical depth for PAR $\left(\zeta\right.$, dimensionless), $\mathrm{NO}^{-3}$ concentration $(N$, $\mu \mathrm{M})$ and distance from the nitracline $(D, \mathrm{~m})$. Shown are the variables selected at the 0.05 significance level and the multiple, linear-regression equation. The $r^{2}$ values represent the fraction of the total variance explained by the independent variables; $\mathrm{n}$ is the number of observations. Also shown are the best single predictors of $\alpha^{B}$ and $\dot{P}_{\mathrm{m}}^{B}$, their corresponding linear-regression equation, $\mathrm{r}^{2}$ value and sample size

\begin{tabular}{|ccccc|}
\hline $\begin{array}{c}\text { Dependent } \\
\text { variable }\end{array}$ & $\begin{array}{c}\text { Independent } \\
\text { variable(s) }\end{array}$ & $\begin{array}{c}\text { Regression } \\
\text { equation }\end{array}$ & $\mathrm{r}^{2}$ & $\mathrm{n}$ \\
\hline$\alpha^{B}$ & $N, \zeta$ & $0.004+0.004 N+0.02 \zeta$ & 0.78 & 52 \\
$P_{\mathrm{m}}^{B}$ & $\zeta, D$ & $3.24-0.44 \zeta+0.02 D$ & 0.87 & 33 \\
$\alpha^{B}$ & $N$ & $0.011+0.005 N$ & 0.69 & 52 \\
$P_{\mathrm{m}}^{B}$ & $\zeta$ & $4.88-0.66 \zeta$ & 0.76 & 33 \\
\hline
\end{tabular}

noyloxy-fucoxanthin and 19 '-butanoyloxy-fucoxanthin. These carotenoids have an absorption spectrum that is broader (400 to $535 \mathrm{~nm}$ ) compared with the s. Thus, the eukaryotic algae containing closely resembles that of the carotenoid pigments. However, it is difficult to separate the influence of the vertical changes in the spectral quality of the underwater irradiance field from vertical changes in the intensity of light (Kirk 1994). Moreover, introduction of nitrate from the deep water may also promote the abundance of eukaryotic cells at the bottom of the hotic zone (Claustre \& Marty 1995). depth. It has been shown both in field (Veldhuis \& Kraay 1990) and laboratory culture studies, using both Prochlorococcus (Babin et al. 1996) and Synechococcus (Kana et al. 1988), that the intracellular concentration this pigment shows minimal variation when cells are own under different light conditions. Therefore, part variation of chlorophyll-normalised zeaxanthin cell, with the intracellular concentration of zeaxanthin remaining relatively stable.

\section{Variation in phytoplankton absorption}

The vertical changes in pigment composition described above have a marked influence on the absorptive properties of the phytoplankton. Our interest in both the shape and magnitude of algal absorption is 2 -fold. First, the chlorophyll-specific absorption coefficient of phytoplankton, $a_{\mathrm{ph}}^{B}(\lambda)$, is a fundamental input parameter in models of underwater light attenuation (Platt \& Sathyendranath 1988, Morel \& André 1991), and hence we are interested to know its typical magnitude and natural variation. Second, the shape of the absorption spectrum is often used to approximate the photosynthetic action spectrum of phytoplankton in spectral models of primary production. Using quantum-corrected, scaled fluorescence excitation spectra as a proxy for absorption by photosynthetic pigments $a_{\mathrm{ps}}(\lambda)$, Sakshaug et al. (1991) and Sosik \& Mitchell (1995) suggested that absorption by NPPs can introduce a bias in estimations of the spectral dependence of $\alpha(\lambda)$ when $a_{\mathrm{ph}}(\lambda)$ is used to approximate its 
shape and, consequently, in computations of primary production. Therefore, the degree with which NPPs may influence the shape of $a_{\mathrm{ph}}^{B}(\lambda)$ should not be ignored.

In general, there are 2 main sources of variation in the magnitude and shape of $a_{\mathrm{ph}}^{B}(\lambda)$ : changes in pigment composition and changes in pigment packaging (Sathyendranath et al. 1987, Bricaud et al. 1988, Mitchell \& Kiefer 1988). Both sources of variation in the absorption coefficient of marine phytoplankton were examined in the present study.

\section{Pigment composition}

Comparative studies of the optical properties of phytoplankton conducted in different regions of the open ocean have shown that the highest values of $a_{\mathrm{ph}}^{B}(440)$ are found at the surface of highly stratified, picoplankton-dominated waters (Bricaud \& Stramski 1990, Hoepffner \& Sathyendranath 1992, Sosik \& Mitchell 1995, Babin et al. 1996, Lazzara et al. 1996, Allali et al. 1997, Stuart et al. 1998). There are 2 reasons why this is so. First, smaller cells have lower pigment packaging than larger cells of the same intracellular pigment concentration, leading to a higher absorptive efficiency per unit pigment (Platt \& Jassby 1976, Morel \& Bricaud 1981). Second, high proportions of the NPPs, relative to chlorophyll $a$, are present in. surface. waters. In this study NPPs constituted over $40 \%$ of the total pigment weight (Fig. 6) within the mixed layer and were estimated to contribute approximately half of absorption by phytoplankton at $440 \mathrm{~nm}$ in surface samples (Fig. 8).

An increase in the concentration of chlorophyll $b$ relative to chlorophyll $a$ with depth resulted in an increase in the chlorophyll-specific absorption coefficients in the wavebands of chlorophyll $b$ absorption (Fig. 7). The shoulders found at 470 to 480 and $650 \mathrm{~nm}$, which are characteristic of samples taken in the deeper layers of blue subtropical waters (Bricaud \& Stramski 1990, Hoepffner \& Sathyendranath 1992, Lazzara et al. 1996, Allali et al. 1997), are caused by a marked increase in the concentration of divinyl chlorophyll $b$ within and below the DCM.

\section{Pigment packaging}

Mathematically, pigment packaging has been expressed as a function of 2 optical properties of phytoplankton: cell size and intracellular pigment concentration (Platt \& Jassby 1976, Morel \& Bricaud 1981). Thus, the package effect can be calculated from the average cell diameter, cell number and pigment con- centrations (Morel \& Bricaud 1981): To estimate the magnitude of the package effect in field samples is more difficult, since the size distribution and abundance of phytoplankton are often unknown. One means of estimating the effect of pigment packaging on the absorption spectrum of a mixed assemblage of cells is to compare the chlorophyll-specific absorption at the red absorption peak, which occurs at $676 \mathrm{~nm}$, with the specific-absorption of pure chlorophyll $a$ in acetone, which is $0.0207 \mathrm{~m}^{2}\left(\mathrm{mg} \mathrm{chl} \mathrm{a}^{-1}\right.$ (Bricaud et al. 1983, 1995, Allali et al. 1997). Absorption at the $6.76 \mathrm{~nm}$ waveband is due predominantly to chlorophyll $a$; the influence of accessory pigments on it is usually minor when compared with that on the blue absorption peak. However, in cases where interference by auxiliary pigments is substantial at $676 \mathrm{~nm}$, a correction should be applied to derive the absorption due to chlorophyll $a$ alone, since it is this that must be compared with the absorption of pure chlorophyll $a$ in solution.

The in vivo pigment-specific absorption coefficient for chlorophyll $a$ at $676 \mathrm{~nm}\left[p^{B}(676)\right]$ obtained using the Gaussian decomposition method of Hoepffner \& Sathyendranath (1993), was found to be greater than the absorption coefficient for chlorophyll $a$ in acetone (Fig. 10). Three types of errors might contribute to these high values of $p^{B}(676)$.

First, the correction for the influence of accessory pigments on the magnitude of the red absorption peak could be in error. If the Gaussian decomposition method underestimated the contribution of chlorophyll $b$ to phytoplankton absorption at the $676 \mathrm{~nm}$ waveband, this would lead to an overestimation of $p^{B}(676)$. Second, the application of an unsuitable $\beta$-correction factor could also result in the overestimation of $p^{B}(676)$.

Although there is no direct way to determine whether chlorophyll $b$ was adequately accounted for in the decomposition of the absorption spectra, there did appear to be a strong relationship between the chlorophyll $b$ peak height at ca $650 \mathrm{~nm}$ determined by the Gaussian decomposition method and the chlorophyll $b$ concentration. Linear regression of the peak heights at $650 \mathrm{~nm}$ and chlorophyll $b$ concentration data yielded an $\mathrm{r}^{2}$ value of 0.84 . Furthermore, values of $p^{B}(676)$ obtained from surface samples, which had negligible concentrations of chlorophyll $b$, were as high as values of $p^{B}(676)$ derived from samples collected at depth that contained extremely high concentrations of chlorophyll $b$. Therefore, a priori, we have no reason to suppose that the high values of $p^{B}(676)$ reflect residual influence of chlorophyll $b$ on the decomposed peak.

Studies by Moore et al. (1995) and Allali et al. (1997) have shown that applying a $\beta$-factor derived from diatom cultures to absorption measurements of picoplankton cells retained on a filter could result in a sig- 
nificant overestimation of phytoplankton absorption in suspension (Moore et al. 1995, Allali et al. 1997). Our pathlength-amplification algorithm takes into account the contribution of small and large cells to total absorption based on the proportion of total chlorophyll a concentration that is divinyl chlorophyll $a$, and applies separate $\beta$-factors to the samples accordingly. However, the algorithm does not consider the possibility that divinyl chlorophyll a-containing prochlorophyte cells would have a higher absorption efficiency than the other groups of phytoplankton containing regular chlorophyll a (Morel et al. 1993). This could, in turn, lead to an overestimation of $a_{\mathrm{ph}}(\lambda)$.

It is apparent from these results that there remains a high level of uncertainty associated with the application of $\beta$-factors to field-based measurements of phytoplankton absorption. Resolving this problem will require a greater understanding of the variation in the relationship between absorption measurements conducted on a filter and those done in suspension.

Extremely high absorption efficiencies could also arise in instances of incomplete extraction of the chlorophyll a pigment. Maske et al. (1996) found that for Synechococcus cells the extraction of chlorophyll a was not as efficient as for eukaryotic cells. If this difficulty of pigment extraction also applies to Prochlorococcus, then any negative bias introduced to our chlorophyll a data could also result in an overestimate of $a_{\mathrm{ph}}^{B}(\lambda)$.

If we accept $0.0207 \mathrm{~m}^{2}\left(\mathrm{mg} \mathrm{chl} \mathrm{a)^{-1 }}\right.$ as an upper limit for the specific absorption coefficient of chlorophyll $a_{\text {, }}$ then our estimates of $p^{\mathrm{B}}(676)$ would be biased. However, the value $0.0207 \mathrm{~m}^{2}(\mathrm{mg} \mathrm{chl} \mathrm{a})^{-1}$ relates to absorption by chlorophyll $a$ in acetone and a degree of uncertainty remains as to the true absorption coefficient of unpacked chlorophyll $a$ within phytoplankton cells. Johnsen et al. (1994) reported unpacked absorption coefficients of protein-bound chlorophyll $a$ at $676 \mathrm{~nm}$ of $0.027 \mathrm{~m}^{2}(\mathrm{mg} \mathrm{chl} \mathrm{a})^{-1}$ in cultures of dinoflagellates, and suggested that pigments attached to proteins may be more efficient at harvesting light energy than when detached.

\section{Variation in the P-I parameters}

Accompanying the vertical changes in the pigment composition and optical properties of subtropical phytoplankton, there was also a strong depth dependence in physiological response of the algae to available irradiance (Fig. 10). At all 5 stations there was a progressive vertical change in the photosynthetic parameters within the mixed layer, indicating that the rate of vertical mixing was slower than the rate of photoacclimation (Cullen \& Lewis 1988). In oligotrophic subtropical waters, the slow rate of vertical mixing, combined with the presence of extremely small cells with low sinking rates, allows phytoplankton cells to maintain their vertical position in the water column long enough to allow the cells to become acclimated to ambient light conditions.

Within and below the DCM, a sharp change in the parameters is seen: $\alpha^{B}$ increased, whereas $P_{\mathrm{m}}^{B}$ and $I_{k}$ decreased. Such patterns in the photosynthetic parameters are characteristic of stratified, open-ocean conditions and are usually attributed to photoacclimation of cells to the irradiance field (Falkowski 1980, Platt et al. 1980, Cullen et al. 1992, Babin et al. 1996). Yet, as we have seen in the data presented in the current study, in addition to the vertical gradients of irradiance, vertical changes in both algal community composition and nutrient concentrations also occur, and are known to cause variation in the P-I parameters. Therefore, it is important to keep in mind that the observed variation in the magnitude of these parameters with depth probably results from a combination of several biological and physico-chemical factors, as will be discussed next.

\section{Relationship between the P-I parameters and environmental co-variables}

Several environmental variables are known to affect the physiological status of phytoplankton cells. Therefore, one might expect that vertical gradients in such physico-chemical properties as nutrient concentration, light and temperature that are found in (sub)tropical waters would have an impact upon the vertical structure of the physiological parameters of phytoplankton. Isolating the variance in $\alpha^{B}$ and $P_{\mathrm{m}}^{B}$ caused by any single environmental variable from those caused by changes in other environmental and biological properties is often not possible. In many cases 1 environmental variable co-varies with several others; this frustrates attempts to determine the cause of variation in the physiological parameters (Sosik 1996).

However, by using a multiple, linear-regression approach we can attempt to determine the key environmental factors that can serve as predictors of photosynthetic performance in the natural environment (Sosik 1996, Kyewalyanga et al. 1998). The results of such analyses can then be compared with those found in laboratory studies to determine whether such relationships are physiologically meaningful. If robust relationships between a few commonly measured, predictor variables and the P-I parameters could be established for a given region and season, then our ability to extrapolate the P-I parameters over large hydrographic regions would be greatly enhanced. 
In this study, optical depth and either nitrate concentration or distance from the nitricline were the best set of predictors of the photosynthetic parameters $P_{\mathrm{m}}^{B}$ and $\alpha^{B}$, respectively (Table 2 ). In general, the signs of the partial correlation coefficients concur with experimen: tal observations with the exception of the positive correlation between distance from the nitricline $(D)$ and $P_{\mathrm{m}}^{B}$. The positive correlation between $D$ and $P_{\mathrm{m}}^{B}$ is likely caused by a high correlation between optical depth and $D$. As a single predictor, optical depth could still account for $76 \%$ of the total variance in $P_{m}^{B}$. The best single predictor of the intial slope $\alpha^{B}$ was nitrate concentration, which could explain $69 \%$ of the total variance. These results also correspond well with those of other studies that examined the natural variability in phytoplankton photosythetic response to changes in environmental conditions. Sosik (1996) reported that a large portion of the total variance in maximum quantum yield could be predicted by temperature, optical depth and distance from the nitricline. Babin et al. (1996) reported a strong correlation between maximum quantum yield and nitrate concentration. Results from a study conducted by Platt et al. (1992) also showed a strong relationship between nitrate concentration and $\alpha^{B}$.

At the spatial scale examined in this study it would appear that the physiological parameters can be predicted by a few routinely measured variables. The apparent robustness of these relationships suggests that the 5 stations sampled were subject to the same physical forcing during the period sampled. The predictable nature of both the optical and physiological properties of the phytoplankton assemblages sampled provides promise that the variation in the P-I parameters may be expressed using more-commonly measured environmental variables.

\section{Concluding remarks}

One of the major problems faced by modellers of primary production is extrapolation of physiological and bio-optical parameters over sparsely-sampled regions, such as the subtropical Atlantic (Longhurst et al. 1995, Sathyendranath et al. 1995). The photosynthetic and bio-optical properties of phytoplankton, as well as the physio-chemical variables that influence them, are known to vary in space and time. Therefore, whenever possible, effort should be made to obtain information both on the magnitude and variation of the physiological parameters and absorptive properties of phytoplankton and on the environmental variables that can be used as predictors of this variation. Such studies will further our understanding of the principal mechanisms regulating photosynthesis in the marine environment as well as:improve upon our parameterisation of the optical and photosynthetic properties of phytoplankton in models of primary production. One of the major aims of this study was to examine the spatial variation of several of the key biological parameters used in photosynthesis models throughout a large region of the subtropical open ocean.

Results obtained at 5 stratified, subtropical stations show similar vertical patterns in algal abundance and community composition, optical and photosynthetic characteristics over large spatial scales. The constancy in species and pigment composition was reflected in the vertical structure of the chlorophyll-specific absorption coefficients of the phytoplankton. The depthdependent change in $a_{\mathrm{ph}}^{B}(440)$ was pronounced and was shown to be influenced strongly by the presence of the NPP zeaxanthin. The strong absorption by NPPs observed in the present study has been documented in other optical studies of subtropical waters (Babin et al. 1996, Lazzara et al. 1996, Allali et al. 1997). The percentage of absorption by NPPs appeared to be highly correlated to irradiance: such consistent trends may be exploited in the construction of primary production models.

Although dividing the world ocean into regions characterised by particular physical and biological properties may be, at present, the most favourable strategy for incorporating spatial and temporal variation in P-I parameters into models of primary production (Longhurst et al. 1995, Sathyendranath et al. 1995), there is still promise that, in the future, P-I parameters may be predicted from more-commonly-measured environmental variables (Platt \& Sathyendranath 1993, Sosik 1996). Previous studies have shown that the correlations between environmental variables and photosynthetic parameters are not universal, but vary both spatially and temporally (e.g. Kyewalyanga et al. 1998). However, if robust seasonal trends can be established for oceanic domains that are subject to different physical forcings, we may be able to incorporate this information into computations for each separate region. Such a strategy can be used both to model and to predict marine primary production on basin to global scales. The results obtained from this study region suggest that, by incorporating information on some commonly-measured environmental variables, a significant portion of the total variation in the P-I parameters can be predicted.

Acknowledgements. We thank all the scientific staff members that participated in the DCM cruise, especially Marcel Veldhuis for providing the flow cytometric data, Kees Veth and Margriet Hiehle for access to the CTD data, Karl Bakker for providing the nutrient data and Taco de Bruin for providing data management support for the expedition. We also thank the officers and crew of RV 'Tydeman' for their co-operation 
throughout the DCM cruise. This work was supported by Natural Sciences and Engineering Research Council of Canada operating grants to T.P. and S.S. This work was carried out as part of the Canadian contribution to the Joint Global Ocean Flux Study (JFOFS). The expedition was supported by the Netherlands Geosciences Foundation (GOA) with additional financial aid from the Netherlands Organization for Scientific Research (NWO), the Netherlands Institute of Sea Research (NIOZ), University of Groningen (Department of Marine Biology) and the Bedford Institute of Oceanography.

\section{LITERATURE CITED}

Allali K, Bricaud A, Claustre $H$ (1997) Spatial variations in the chlorophyll-specific absorption coefficients of phytoplankton and photosynthetically active pigments in the equatorial Pacific. J Geophys Res 102:12413-12423

Arrigo KR, Sullivan CW (1992) The influence of salinity and temperature covariation on the photophysiological characteristics of Antarctic sea ice microalgae. J Phycol 28: 746-756

Babin M, Therriault JC, Legendre L, Nieke B, Reuter R, Condal A (1995) Relationship between the maximum quantum yield of carbon fixation and the minimum quantum yield

" of chlorophyll $a$ in vivo fluorescence in the Gulf of St. Lawrence. Limnol Oceanogr 40:956-968

Babin M, Morel A, Claustre $H$, Bricaud A, Kolber Z, Falkowski PJ (1996) Nitrogen- and irradiance-dependent variations of maximum quantum yield of carbon fixation in eutrophic, mesotrophic and oligotrophic marine systems. Deep-Sea Res 43:1241-1272

Bidigare RR, Ondrusek ME, Marrow JH, Kiefer DA (1990) In vivo absorption of algal pigments. SPIE 1302:290-302

Bouman HA, Platt $T$, Sathyendranath $S$, Irwin BD, Wernand MR, Kraay GW (2000) Bio-optical properties of the subtropical North Atlantic. II. Relevance to models of primary production. Mar Ecol Prog Ser 200:19-34

Bricaud A, Stramski D (1990) Spectral absorption coefficients , of living phytoplankton and nonalgal biogenous matter: a comparison between the Peru upwelling area and the Sargasso Sea. Limnol Oceanogr 35:562-582

Bricaud A, Morel A, Prieur L (1983) Optical efficiency factors of some phytoplankters. Limnol Oceanogr 28:816-832

Bricaud A, Bédhomme AL, Morel A (1988) Optical properties of diverse phytoplanktonic species: experimental results and theoretical interpretation. J Plankton Res 10:851-873

Bricaud A, Babin M, Morel A, Claustre H (1995) Variability in the chlorophyll-specific absorption coefficients of natural phytoplankton: analysis and parameterization. J Geophys Res 100:13321-13332

Claustre H, Marty JC (1995) Specific phytoplankton biomasses and their relation to primary production in the tropical North Atlantic. Deep-Sea Res 42:1475-1493

Cullen JJ (1982) The deep chlorophyll maximum: comparing vertical profiles of chlorophyll a. Can J Fish Aquat Sci 39: 791-803

Cullen JJ, Lewis MR (1988) The kinetics of algal photoadaptation in the context of vertical mixing. J Plankton Res 10 : 1039-1063

Cullen JJ, Lewis MR, Davis CO, Barber RT (1992) Photosynthetic characteristics and estimated growth rates indicate grazing is the proximate control of primary production in the equatorial Pacific. J Geophys Res 97:639-654

Dubinsky Z, Falkowski PG, Wyman K (1986) Light harvesting and utilization by phytoplankton. Plant Cell Physiol 27: 1335-1349
Duysens LNM (1956) The flattening of the absorption spectrum of suspensions, as compared to that of solutions. Biochim Biophys Acta 19:1-12

Falkowski PG (1980) Light-shade adaptation in marine phytoplankton. In: Falkowski PG (ed) Primary productivity in the sea. Plenum, New York, p 99-120

Gibbs CF (1979) Chlorophyll $b$ interference in the flourometric determination of chlorophyll $a$ and 'phaeopigments'. Aust J Mar Freshw Res 30:597-606

Goericke R, Repeta DJ (1993) Chlorophylls $a$ and $b$ and divinyl chlorophylls $a$ and $b$ in the open subtropical North Atlantic Ocean. Mar Ecol Prog Ser 101:307-313

Haxo FT, Blinks LR (1950) Photosynthetic action spectra of marine algae. J Gen Physiol 33:389-422

Herbland A (1983) Le maximum de chlorophylle dans l'Atlantique tropical oriental: description, écologie, interprétation. Oceanogr Trop 18:295-318

Hoepffner N, Sathyendranath S (1992) Bio-optical characteristics of coastal waters: absorption spectra of phytoplankton and pigment distribution in the western North Atlantic. Limnol Oceanogr 37:1660-1679

-Hoepffner N, Sathyendranath S (1993) Determination of the major groups of phytoplankton pigments from the absorption spectra of total particulate matter. J Geophys Res 98 : 22789-22803

Holm-Hansen O, Lorenzen CJ, Holmes JDH (1965) Fluorometric determination of chlorophyll. J Cons Int Explor Mer 30:3-15

Johnsen G, Nelson NB, Jovine RVM, Prézelin, BB (1994) Chromoprotein- and pigment-dependent modeling of spectral light absorption in two dinoflagellates, Prorocentrum minimum and Heterocapsa pygmaea. Mar Ecol Prog Ser $114: 245-258$

Kana TM, Glibert PM, Goericke R, Welschmeyer NA (1988) Zeaxanthin and $\beta$ carotene in Synechococcus WH7803 respond differently to irradiance. Limnol Oceanogr 33: 1623-1627

Kirk JTO (1976) A theoretical analysis of the contribution of algal cells to the attenuation of light within natural waters. IIl. Cylindrical and spheroidal cells. New Phytol 77:341-358

Kirk JTO (1994) Light and photosynthesis in aquatic ecosystems. Cambridge University Press, Cambridge

Kishino M, Takahashi M, Okami N, Ichimura S (1985) Estimation of the spectral absorption coefficients of phytoplankton in the sea. Bull Mar Sci 37:634-642

Kraay GW, Zapata M, Veldhuis MJW (1992) Separation of chlorophylls $c 1, c 2$, and $c 3$ of marine phytoplankton by reversed-phase-c18-high-performance liquid chromatography. J Phycol 28:708-712

Kyewalyanga MN, Platt T, Sathyendranath S (1997) Estimation of the photosynthetic action spectrum: implication for primary production models. Mar Ecol Prog Ser 146: 207-223

Kyewalyanga MN, Platt T, Sathyendranath S, Lutz VA, Stuart $V$ (1998) Seasonal variations in physiological parameters of phytoplankton across the North Atlantic. J Plankton Res 20:17-42

Lazzara L, Bricaud A, Claustre H (1996) Spectral absorption and fluorescence excitation properties of phytoplanktonic populations at a mesotrophic and an oligotrophic site in the tropical North Atlantic (EUMELI program). Deep-Sea Res 43:1215-1240

Longhurst A, Sathyendranath S, Platt T, Caverhill C (1995) An estimate of global primary production in the ocean from satellite radiometer data. J Plankton Res 17:1245-1271

Maske H, Duarte RC, Hernández CD (1996) Phytoplankton pigment extraction efficiency and the specific in vivo ab- 
sorption of phytoplankton. J Phycol (Suppl) 32:30-31

Mitchell BG, Kiefer DA (1988) Chlorophyll a specific absorption and fluorescence excitation spectra for light-limited phytoplankton. Deep-Sea Res 35:639-663

Moore LR, Goericke R, Chisholm SW (1995) Comparative physiology of Synechococcus and Prochlorococcus: influence of light and temperature on growth, pigments, fluorescence and absorptive properties. Mar Ecol Prog Ser $116: 259-275$

Moore LR, Rocap G, Chisholm SW (1998) Physiology and molecular phylogeny of coexisting Prochlorococcus ecotypes. Nature 393:464-467

Morel A, André JM (1991) Pigment distribution and primary production in the western Mediterranean as derived and modeled from Coastal Zone Color Scanner observations. J Geophys Res 96:12685-12698

Morel A, Bricaud A (1981) Theoretical results concerning the optics of phytoplankton, with special reference to remote sensing äpplications. In: Gower JFR (ed) Oceanography from space. Plenum, New York, p 313-327

Morel A, Ahn YH, Pertensky F, Vaulot D, Claustre H (1993) Prochlorococcus and Synechococcus: a comparative study of their optical properties in relation to their size and pigmentation. J Mar Res 51:617-649

Partensky F, Hoepffner N, Li WKW, Ulloa O, Vaulot D (1993) Photiacclimation of Prochlorococcus sp. (Prochlorophyta) strains isolated from the North Atlantic and the Mediterranean Sea. Plant Physiol (Rockv) 101:285-296

Partensky F, Blanchot J, Lantoine F, Nevuax J, Marie D (1996) Vertical structure of picophytoplankton at different trophic sites of the tropical northeastern Atlantic Ocean. Deep-Sea Res 43:1191-1213

Platt T, Jassby AD (1976) The relationship between photosynthesis and light for natural assemblages of coastal marine phytoplankton. J Phycol 12:421-430

Platt T, Sathyendranath S (1988) Oceanic primary production: estimation by remote sensing at local and regional scales. Science 241:1613-1620

Platt T, Sathyendranath S (1993) Estimators of primary production for interpretation of remotely sensed data on ocean color. J Geophys Res 98:14561-14576

Platt T, Gallegos CL, Harrison WG (1980) Photoinhibition of photosynthesis in natural assemblages of marine phytoplankton. J Mar Res 38:687-701

Platt T, Caverhill C, Sathyendranath S (1991) Basin-scale estimates of oceanic primary production by remote sensing: the North Atlantic. J Geophys Res 96:15147-15159

Platt T, Sathyendranath $S$, Ulloa $O$, Harrison WG, Hoepffner

Editorial responsibility: Otto Kinne (Editor),

Oldendorf/Luhe, Germany
N, Goes J (1992) Nutrient control of phytoplankton photosynthesis in the wëstern North Atlantic. Nature 356: $229-231$

Sakshaug E, Johnsen G, Andresen K, Vernet M (1991) Modeling of light-dependent algal photosynthesis and growth: experiments with the Barents Sea diatoms Thalassiosira nordenskioeldii and Chaetoceros furcellatus. Deep-Sea Res 38:415-430

Sathyendranath S, Platt T (1989) Computation of aquatic primary production: extended formalism to include effect of angular and spectral distribution of light. Limnol Oceanogr 34:188-198

Sathyendranath S, Lazzara L, Prieur L (1987) Variations in the spectral values of specific absorption of phytoplankton. Limnol Oceanogr 32:403-415

Sathyendranath S, Longhurst A, Caverhill CM, Platt T (1995) Regionally and seasonally differentiated primary production in the North Atlantic. Deep-Sea Res 42:1773-1802

Schofield O, Prézelin BB, Smith RC, Stegmann PM, Nelson NB, Lewis MR, Baker KS (1991) Variability in spectral and nonspectral measurements of photosynthetic light utilization efficiencies. Mar Ecol Prog Ser 78:253-271

Sosik HM (1996) Bio-optical modeling of primary production: consequences of variability in quantum yield and specific absorption. Mar Ecol Prog Ser 143:225-238

Sosik HM, Mitchell BG (1995) Light absorption by phytoplankton, photosynthetic pigments and detritus in the California Current System. Deep-Sea Res 42:1717-1748

Stuart V, Sathyendranath S, Platt T, Maass H, Irwin BD (1998) Pigments and species composition of natural phytoplankton populations: effect on the absorption spectra. J Plankton Res 20:187-217

Veldhuis MJW, Kraay GW (1990) Vertical distribution and pigment composition of a picoplankton prochlorophyte in the subtropical North Atlantic: a combined study of HPLCanalysis of pigments and flow cytometry. Mar Ecol Prog Ser 68:121-127

Wernand MR, Spitzer D (1987) Processing of underwater spectra collected by ASIR (Advanced Spectr. IRad.meter) in the Madura Bay. In: Proceedings of the joint DFVLRLAPAN-NIOZ workshop on remote sensing of the sea. Participation in the Snellius II expedition 1984, January 14 to 16, 1987. Jakarta, Indonesia, Reference Publication, TKH 8705, Indonesian National Institute of Aeronatics and Space (LAPAN), Jakarta, p 160-166

Wood AM (1985) Adaptation of photosynthetic apparatus of marine ultraphytoplankton to natural light fields. Nature 316:253-255

Submitted: June 14, 1999; Accepted: November 5, 1999 Proofs received from author(s): June 21, 2000 